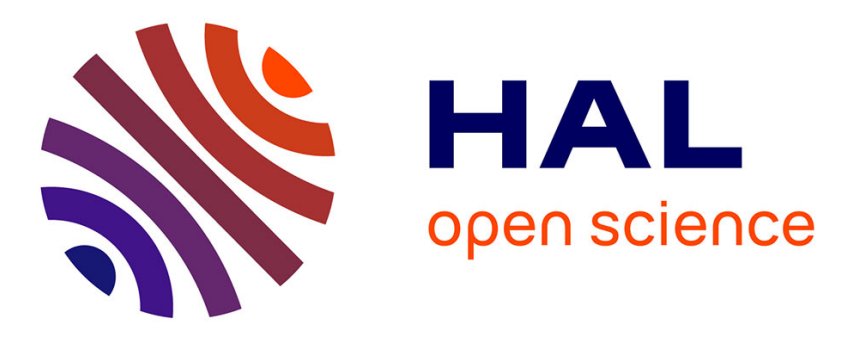

\title{
Potassic late orogenic Stephanian volcanism in the South West french Massif Central (Decazeville, Figeac, Lacapelle-Marival basins): an example for mantle metasomatism along strike-slip faults?
}

Henriette Lapierre, Christophe Basile, Thomas Berly, Emmanuel Canard

\section{To cite this version:}

Henriette Lapierre, Christophe Basile, Thomas Berly, Emmanuel Canard. Potassic late orogenic Stephanian volcanism in the South West french Massif Central (Decazeville, Figeac, LacapelleMarival basins): an example for mantle metasomatism along strike-slip faults?. Bulletin de la Société Géologique de France, 2008, 179 (5), pp.491-502. hal-00138515v2

\author{
HAL Id: hal-00138515 \\ https://hal.science/hal-00138515v2
}

Submitted on 24 Oct 2007

HAL is a multi-disciplinary open access archive for the deposit and dissemination of scientific research documents, whether they are published or not. The documents may come from teaching and research institutions in France or abroad, or from public or private research centers.
L'archive ouverte pluridisciplinaire $\mathbf{H A L}$, est destinée au dépôt et à la diffusion de documents scientifiques de niveau recherche, publiés ou non, émanant des établissements d'enseignement et de recherche français ou étrangers, des laboratoires publics ou privés. 


\section{Potassic late orogenic Stephanian volcanism in the South West French Massif central}

(Decazeville, Figeac, Lacapelle-Marival basins): an example for mantle metasomatism along strike-slip faults?

H. Lapierre ${ }^{\dagger}$, C. Basile*, T. Berly, E. Canard

Laboratoire de Géodynamique des Chaînes Alpines, CNRS UMR 5025, Observatoire des Sciences de l'Univers de Grenoble, Université Joseph Fourier. Maison des Géosciences, 1381 rue de la Piscine, 38400 St Martin d'Hères, France.

$\dagger$ Deceased in January 2006

* Corresponding author cbasile@ujf-grenoble.fr

Keywords: late orogenic magmatism, shoshonitic magma, metasomatism, Sillon Houiller fault, Variscan

Mots clefs: magmatisme tardi-orogénique, shoshonitique, métasomatisme, Sillon Houiller, Varisque

\section{Abstract}

In the Southwestern part of the French Massif central (Decazeville basin, at the Sillon Houiller fault termination; Figeac and Lacapelle-Marival basins along the Argentat fault), Stephanian volcanism exhibits shoshonitic affinities. Their chondrite-normalized Rare Earth Element (REE) patterns are enriched in light REE, but almost flat for heavy REE, with marked negative Eu anomalies. Primitive mantle-normalized element spectra show negative $\mathrm{Nb}, \mathrm{Ta}, \mathrm{P}, \mathrm{Sm}, \mathrm{Ti}$, and positive $\mathrm{Th}, \mathrm{U}, \mathrm{Pb}$ anomalies, respectively. $\varepsilon_{\mathrm{Nd}}$ values are negative and homogeneous (-6 to -4$)$. This volcanism shares the same geochemical patterns as the late- 
orogenic Stephanian-Permian magmatism from the southern part of the Variscan belt (Pyrénées, Alps, Sardinia). We explain these geochemical characteristics as resulting from the partial melting of a metasomatised mantle. We propose a new mechanism to explain this melting process: horizontal displacement along the main late-orogenic strike-slip faults might bring into contact a hydrated lower crust with the lithospheric mantle. Mantle metasomatism within the strike-slip fault zone may then induce partial melting.

\section{Résumé}

Le volcanisme Stéphanien du Sud Ouest du Massif central français, observé dans les bassins de Decazeville à l'extrémité du Sillon Houiller, de Figeac et Lacapelle-Marival le long de la faille d'Argentat, présente des caractéristiques géochimiques similaires. Il s'agit d'un magmatisme d'affinité shoshonitique, présentant des spectres de terres rares normalisés aux chondrites enrichis en terre rares légères, mais presque plat pour les terres rares lourdes, avec une anomalie négative en Eu marquée. Les spectres élémentaires normalisés au manteau primitif montrent des anomalies négatives en $\mathrm{Nb}, \mathrm{Ta}, \mathrm{P}, \mathrm{Sm}$ et Ti, et des anomalies positives en Th, $U$ et $P b$. Les valeurs d' $\varepsilon_{N d}$ sont négatives et également très homogènes (-6 à 4). Ce volcanisme présente les mêmes caractéristiques que le volcanisme tardi-orogénique stéphano-permien du Sud de la chaîne varisque (Pyrénées, Alpes, Sardaigne). Ces caractéristiques sont interprétées comme résultant de la fusion partielle d'une source mantellique métasomatisée. Il est proposé un nouveau mécanisme provoquant cette fusion, par l'intermédiaire du déplacement horizontal des failles décrochantes tardi-orogéniques majeures, qui pourrait mettre en contact une croûte inférieure hydratée et le manteau lithosphérique. La métasomatose du manteau dans la zone de faille décrochante provoquerait sa fusion. 


\section{Introduction}

Late orogenic times are key periods in mountain belt evolution, when the continental lithosphere acquires a new structure that will control further evolution, including its reworking in new orogens. The continental crust is particularly modified by late orogenic magmatism and tectonism. Bimodal magmatism is widespread, and results primarily from partial melting of the crust and underlying mantle [Bonin, 2004]. The magmas evolving from mantle melts are commonly potassium-rich [High Potassium Calc Alcaline: HKCA, e.g. Liégeois et al., 1998], but the mechanisms associated with this enrichment are still a matter of discussion [Gibson et al., 1993; Liégeois et al., 1998; Miller et al., 1999; Pecerillo and Martinotti, 2006]. This magmatism is coeval with a change in the tectonic regime, from regional compression to strike-slip, then extensional regime, that precedes the tectonic quiescence [e.g. Blès et al., 1989]. The strike-slip regime generates numerous vertical faults that cross-cut the orogenic structures.

At the end of the Variscan orogeny, Westphalian synkinematic plutonism accommodated extension parallel to the mountain belt [Faure, 1995]. Before the widespread post-orogenic Permian extension, the Stephanian period represents a transition with numerous strike-slip faults and associated intracontinental coal-bearing basins. In the French Massif central, the Sillon Houiller is one of these strike-slip faults (Fig. 1), coeval to the formation of numerous deep and narrow Stephanian basins first infilled with potassic volcanism [Letourneur, 1953]. Potassic volcanism is also known in other Stephanian basins, as for example along the Argentat fault in the western part of the Massif central (Fig. 1). These two faults meet together in the southwestern Massif central, where a comparison of these late orogenic potassic volcanism in coeval strike-slip and extensional basins can be done. 


\section{Geological setting}

The present study focuses on the volcanism located in the Decazeville basin, at the southern termination of the Sillon Houiller, and in Figeac and Lacapelle-Marival basins along the Argentat fault.

The Sillon Houiller fault is a $270 \mathrm{~km}-\mathrm{long}$, nearly N-S to NNE-SSW striking left-lateral fault, which crosses the entire Massif central (Fig. 1). The cumulated horizontal displacement has been estimated as ranging from 70 to 100 kilometres [Grolier and Letourneur, 1968]. This fault has been considered as a transfer fault accommodating differences between NW-SE and NE-SW extension directions on its western and eastern sides [Burg et al., 1990]. However, this interpretation is not supported by the age of extension, which is Namurian-Westphalian for the western NW-SE trend and Stephanian-Autunian for the NE-SW extension [Faure, 1995]. Nevertheless, due to its NNE-SSW trend and connection with coeval Stephanian basins, the Sillon Houiller fault can be considered either as a transfer [Faure, 1995] or transform fault [Basile, 2006] in Stephanian times. The formation of the Decazeville basin was tectonically controlled by its horsetail splay termination in a transtensional regime [Basile, 2006]. In the lowermost part of the basin infilling, a thick volcanic complex overlies coarse conglomerates (Fig. 1). The upper part of the 1800 m-thick sedimentary cross-section is almost devoid of volcanism, expressed only by a few thin layers of tuffs intercalated in lacustrine to deltaic continental sediments.

The Argentat fault is a $160 \mathrm{~km}$-long curved fault in the western part of the Massif central, running from the Bosmoreau Carboniferous basin to the north and the Decazeville basin to the south (Fig. 1). This fault strikes N-S in its northern part and NW-SE in its southern part. The Argentat fault first acted as a right-lateral ductile normal fault, then as a brittle strike-slip fault during the Late Carboniferous [Feix et al., 1987; Roig et al., 1997]. Figeac, St Perdoux and 
Lacapelle-Marival represent the southernmost basins associated with this fault (Fig. 1). They are not directly bound by the Argentat fault, but appear as the Argentat basin located on a basement flexure [Genna et al., 1998]. Due to of Mesozoic sedimentary cover, the connection between Figeac and Lacapelle-Marival basins is presently hidden (Fig. 1), but both basins probably belong to a single one whose remnants were drilled below the Mesozoic sediments [Lefavrais-Raymond et al., 1990]. As for the Decazeville basin, the 300 to $400 \mathrm{~m}$-thick volcanic complex is located at the base of the basin infilling, overlain by coarse detrital sediments. Numerous NW-SE-trending feeder dikes also cross-cut the basement close to the Lacapelle-Marival basin (Fig. 1), providing evidence for a NE-SW extension during volcanism and basin subsidence.

In these basins, sediments are middle Stephanian (Stephanian B) in age, with early Stephanian ages (A) suspected in the St Perdoux basin, and the base of late Stephanian (C) observed in the Decazeville basin (Fig. 1) [Vetter, 1968]. Permian sediments unconformably overlay Stephanian beds in the eastern part of the Decazeville basin. They were also found in the Figeac basin [Lefavrais-Raymond et al., 1990]. The age of volcanism is also assummed to be Stephanian, but this age is controversial in the Decazeville basin. From palynology, the older sediments were dated as the base of middle Stephanian [Vetter, 1968], whereas U-Pb dating on unlocated volcanic zircons provided an older Visean age [333 Ma, Bruguier et al., 1998].

Volcanism is expressed as basalts, intermediate or felsic rocks, mainly as lava flows, but also as ejecta and numerous dikes in the crystalline basement. Morre [1966] and Morre and Quesnel [1967] emphasized the potassium-rich character of these lava, especially in intermediate rocks in which $\mathrm{K}_{2} \mathrm{O}$ ranges from 6 to $11 \%$.

- In the northern part of Decazeville basin, samples were collected from two areas (Fig. 1), the Bouran section along the D963 road (samples CLB95-1 to -8), and the Lot river 
banks on either side of Livinhac bridge (CLB95-9 to -17, and CLB96-1). The Bourran section consists of volcaniclastic rocks and volcanic flows conformably overlain by detrital sediments [Campagnac unit, Vetter, 1968]. The graded bedded volcaniclastic rocks rest unconformably on Variscan micaschists, and consist of breccias and lapilli-tuffs, interlayered with massive volcanic flows. The breccias are composed of meter-sized volcanic blocks caught in a tuffaceous matrix while the lapilli-tuffs include centimeter-sized angular volcanic fragments. The lapilli-tuffs locally grade to millimeter-sized crystal tuffs. Near Livinhac, massive basalts are exposed on both sides of the Lot river. The northern outcrop is cross-cutted by a porphyric dike (CLB95-17).

- In the Figeac area, two sections were sampled, East (Célé) and North (Planioles) of the city, respectively (Fig. 1). Along the Planioles section, hyalopilitic basalts crop out (CLB96-3). They are successively overlain by vitric tuffs, very altered rhyolites (CLB96-2) and detrital sediments. In the Célé valley, two outcrops of massive flows of intermediate composition (CLB96-5) can be found.

- Near Lacapelle-Marival, two volcanic levels are interbedded with Carboniferous shales, sandstones and conglomerates. Sampling concerns massive flows of mafic to intermediate composition in the northern part of the basin (CLB96-13 to -17) and small outcrops of intermediate to acidic lavas to the south (CLB96-6 to -12, Fig. 1).

\section{Petrography and mineralogy}

The studied volcanic rocks are frequently severely weathered. Plagioclase is often replaced by albite or sericite, or even quartz and epidote. Olivine is transformed to iddingsite, serpentine or smectites. Orthopyroxene and clinopyroxene remain more commonly fresh. Biotite and hornblende are often chloritized. When altered, Ti-rich oxides are filled with 
titanite. Mafic glass has crystallized into chlorite \pm smectites while vesicles are filled with calcite or smectites. The groundmass of intermediate lavas and rhyolites consists of fine grained quartz associated with alkali feldspar (albite or adularia). As no metamorphism has been observed in the sediments overlying the lavas, the occurence of chlorite probably indicates hydrothermal alteration coeval with lava eruption.

In both Decazeville and Lacapelle-Marival basins, mafic rocks are commonly glomeroporphyritic with clots of large zoned plagioclase, orthopyroxene and clinopyroxene. These phenocrysts are associated with either olivine or amphibole and biotite \pm quartz. The groundmass includes plagioclase microliths and oxides. Quartz xenocrysts rimmed by orthopyroxene may occur. In Lacapelle-Marival area, some basalts differ by their trachytoid texture that consists of plagioclase laths $(30 \%)$ and less abundant larger phenocrysts $(\sim 10$ $\%)$. The intermediate lavas exhibit seriate textures with millimeter-sized alkali feldspar phenocrysts. Their groundmass includes sandstone inclusions and quartz-filled flattenned vesicles. The rhyolites display quartz and feldspar phenocrysts $(20 \%)$ and biotite needles ( $10 \%$ ), that includes apatite and zircon. The Figeac rhyolites differ from those from LacapelleMarival by the presence of green hornblende.

When preserved (CLB95-5, CLB95-16, CLB96-1, CLB96-3), plagioclase composition of mafic volcanic rocks varies from Ca-rich cores $\left(\mathrm{An}_{98-60}\right)$ to Na-rich rims $\left(\mathrm{An}_{50-40}\right)$. Preserved alkali feldspar (CLB96-11) gives sanidine compositions (Ab57-66). Clinopyroxene phenocrysts (CLB96-1, CLB95-16, CLB95-5) show homogeneous augite compositions [Wo39-44 En E4-52 $_{4}$ $\mathrm{Fs}_{12-21}$; Morimoto et al. 1988], while preserved orthopyroxene (CLB95-5, CLB95-16) has bronzite compositions $\left(\mathrm{Wo}_{2-2.5} \mathrm{En}_{77-78} \mathrm{Fs}_{19-21}\right)$. 


\section{Geochemistry}

\section{$\underline{\text { Analytical techniques }}$}

Thirty one samples have been analysed for whole rock major- and trace-element concentrations. Among them, twenty one have been analysed for $\mathrm{Nd}$, and nine for $\mathrm{Sr}$ isotopic chemistry (tabl. I). Major and compatible trace-elements have been measured by ICP-AES at the Centre de Recherches Pétrographiques et Géochimiques de Nancy (samples CLB95) or by X-ray fluorescence $(\mathrm{XRF})$ at the Earth Sciences Department of the Australian National University at Canberra (Australia) (samples CLB96). The trace-element concentrations have been determined by inductively coupled plasma-mass spectrometry (ICP-MS, VG-PQ ${ }^{2+}$ ) at the Laboratoire de Géodynamique des Chaînes Alpines de l'Université Joseph Fourier (Grenoble), after acid dissolution, using the procedures described by Barrat et al. [1996]. Standards used for the analyses were JB2, WSE, BIR-1, JR1, and BHVO.

$\mathrm{Sr}$ and $\mathrm{Nd}$ isotopic ratios were measured at the Laboratoire de Géochimie isotopique de l'Université Paul Sabatier (Toulouse), on a Finnigan MAT261 multicollector mass spectrometer using the analytical procedures of Lapierre et al. [1997]. Results on La Jolla Nd standards yielded ${ }^{143} \mathrm{Nd} /{ }^{144} \mathrm{Nd}=0.511850 \pm 8$ (mean on 39 runs). Results on NBS $987 \mathrm{Sr}$ standard yielded ${ }^{87} \mathrm{Sr} /{ }^{86} \mathrm{Sr}=0.710250 \pm 5$ (mean on 200 runs). The isotopic data have been corrected for "in situ decay" for an age of $300 \mathrm{Ma}$.

\section{$\underline{\text { Alteration and elemental mobility }}$}

Most of the analysed rocks have a loss on ignition lower than 6\% (LOI, tabl. I), due to the presence of calcite- or smectites-filled vesicules. Moreover, the altered nature of the studied Carboniferous volcanic rocks means that before any petrological inferences can be drawn from their chemistry, possible effects of subsolidus transformations must be considered. 
As Zirconium $(\mathrm{Zr})$ is considered to be immobile during low-grade alteration of igneous rocks of mafic to felsic composition by hydrothermal fluids [Gibson et al., 1982], it has been used ot test the mobility of minor $\left(\mathrm{TiO}_{2}\right)$, and incompatible trace elements $(\mathrm{Rb}, \mathrm{Sr}, \mathrm{Pb}, \mathrm{La}$, $\mathrm{Nb}, \mathrm{Y}, \mathrm{U}$ and $\mathrm{Th}$ ) in figure $2 . \mathrm{Rb}, \mathrm{Sr}, \mathrm{Pb}$ and $\mathrm{La}$ do not display any correlation with $\mathrm{Zr}$. This implies that Large Ion Lithophile Elements (LILE) have been extensively mobilised. For example, some samples are enriched in $\mathrm{Pb}$ (others in $\mathrm{Ba}$ ), probably in relation with hydrothermal circulations [Marignac and Cuney, 1999]. Thus, variations in LILE are not expected to reflect the composition of the sources ( $\mathrm{Sr}$ isotopic ratios) or the magmatic processes. These variations will not be discussed further on. Similarly, the behaviour of K and $\mathrm{Ca}$ also exclude their use for sample classification.

In contrast, other elements such as $\mathrm{U}, \mathrm{Th}, \mathrm{Nb}$ or $\mathrm{TiO}_{2}$ correlate rather well with $\mathrm{Zr}$, suggesting relative immobility. However, some samples (CLB95-17, 95-15, 95-1, 96-5) differ from the correlation trend on the $\mathrm{Nb}-\mathrm{Zr}$ plot. The same samples, together with CLB95-6, 9512, 96-2, 96-8 show a negative correlation on the $\mathrm{TiO}_{2}-\mathrm{Zr}$ diagram, while all other samples exhibit a positive correlation. CLB95-17 is the most mafic sample $\left(\mathrm{SiO}_{2} 51.9 \%, \mathrm{MgO} 7,7 \%\right.$, tabl. I); CLB95-1, 95-6, 95-12, 95-15, 96-2, 96-5, 96-8 represent the most $\mathrm{SiO}_{2}$-rich and $\mathrm{MgO}$-poor samples $\left(\mathrm{SiO}_{2}>65 \%\right.$ and $\mathrm{MgO}<1.3 \%$, tabl. I).

In the $\mathrm{Y}-\mathrm{Zr}$ diagram, each sampling site corresponds to distinct $\mathrm{Y}-\mathrm{Zr}$ correlation trends. This suggests that the Carboniferous volcanic rocks are not related by simple fractionation processes, but rather reflect variations of partial melting ratios, and/or complex fractionation processes dominated by clinopyroxene or amphibole accumulation and/or removal.

\section{$\underline{\text { Volcanic rocks terminology }}$}

Because of the alteration experienced by the Carboniferous volcanic rocks, it was difficult to name the different facies on the basis of mineralogy only, especially for the mafic rocks. 
The various types of volcanic rocks have been discriminated using $\mathrm{Ti}$ and immobile trace elements $\mathrm{Zr}, \mathrm{Nb}$ and $\mathrm{Y}$ (figure 3). The most mafic rock (CLB95-17) plots in the andesite/basalt field. The samples that exhibit a positive correlation in the $\mathrm{TiO}_{2}-\mathrm{Zr}$ diagram (figure 2) have a constant $\mathrm{Zr} / \mathrm{Ti}$ ratio and plot near the fence separating the field or rhyodacites from that of andesites, with the exception of sample 95-13 which plots in the alkali basalt field. Among the most $\mathrm{SiO} 2$-rich samples that show a negative correlation in the $\mathrm{TiO}_{2}-\mathrm{Zr}$ diagram (figure 2), CLB95-1 plots in the trachy-andesite field, CLB95-6, 95-12, 96-2 and 96-8 in the rhyodacite field, CLB96-5 in the rhyolite field and CLB95-15 at the fence between trachyte and comendite.

Because $\mathrm{K}$ is highly mobile during alteration and low grade metamorphism processes, we cannot rely on the $\mathrm{K}$ contents of the Carboniferous volcanic rocks (half of the samples have $\mathrm{K}$ contents from 6 to 12\%) to infer calc-alkaline or shoshonitic affinities. Müller et al. [1992] proposed a $\mathrm{Th} / \mathrm{Yb}$ versus $\mathrm{Ta} / \mathrm{Yb}$ correlation diagram to discriminate arc-tholeiites, calcalkaline and shoshonitic suites. As shown in figure 4, most of the Carboniferous volcanic rocks fall in the shoshonitic field, with the exception of 95-17 andesite/basalt which fall in the calc-alkaline field. In this plot the most $\mathrm{SiO} 2$-rich samples exhibit a more shoshonitic affinity.

\section{Trace-element geochemistry}

Figure 5 illustrates the chondrite-normalized [Sun and McDonough, 1989] Rare Earth Elements (REE) patterns of the Carboniferous volcanic rocks. All the rocks are enriched in Light (L) REE relative to the heavy $(\mathrm{H}) \operatorname{REE}\left[2.8 \leq(\mathrm{La} / \mathrm{Yb})_{\mathrm{n}} \leq 31.9\right]$. However, HREE patterns are either flat or gently sloping, suggesting that LREE enrichment reflects a metasomatised source [Keppler, 1996; Tatsumi and Kogiso, 1997; Beccaluva et al., 2004]. All samples also show negative Eu anomalies $\left(0.38<\mathrm{Eu} / \mathrm{Eu}^{*}<0.84\right)$. These anomalies suggest an early fractionation of plagioclase during magma differentiation. The most SiO2-rich rocks 
(e.g. samples CLB95-1 and -6 in Bourran) are commonly less enriched than mafic rocks (e.g. samples CLB95-4 and -8 in Bourran), especially for HREE (Figure 5). This suggests again that these lavas cannot result from fractional crystallisation of basalts.

There are no significative differences between the sampling sites, with the exception of negative $\mathrm{Ce}$ anomalies $(0.67 \leq \mathrm{Ce} / \mathrm{Ce} * \leq 0.38)$ for four rhyodacites from the southern part of Lacapelle-Marival basin (CLB96-6, CLB96-10 to -12). Two rhyodacites from Decazeville (CLB95-8, CLB95-9) differ from the other rocks by flatter patterns $\left[2.8<(\mathrm{La} / \mathrm{Yb})_{\mathrm{n}}<4.9\right]$. The trachyte from the Livinhac site (CLB95-15) differs from the other felsic rocks by a very steep REE pattern due to an important HREE depletion $\left[(\mathrm{La} / \mathrm{Yb})_{\mathrm{n}}=31.9\right]$.

Figure 6 shows the primitive mantle-normalized spiderdiagrams [Sun and McDonough, 1989]. Whatever their location or mafic character, Carboniferous volcanic rocks exhibit similar trace element patterns, characterized by negative $\mathrm{Nb}, \mathrm{Ta}, \mathrm{P}, \mathrm{Sm}, \mathrm{Ti}$ and positive $\mathrm{Th}, \mathrm{U}$ and $\mathrm{Pb}$ anomalies, respectively. As shown previously (Fig. 2), Sr vary from 10 to $330 \mathrm{ppm}$. The most mafic rocks exhibit a homogeneous composition for all trace elements, with the exception of CLB95-17 that differs from the other mafic rocks by a $\mathrm{Zr}$ and $\mathrm{Hf}$ depletion. CLB95-17 as other samples (CLB95-1, 95-13, 95-15, 96-5) that define a negative trend in TiO2/Zr correlation (Fig. 2) are all characterized by a negative Y anomaly.

\section{$\underline{\mathrm{Nd} \text { and Sr isotopic geochemistry }}$}

The Carboniferous volcanic rocks span a rather small range of $\varepsilon_{\mathrm{Nd}}$ values, from -5.8 to -3.9, with the relative exception of CLB96-5 rhyolite $\left(\varepsilon_{\mathrm{Nd}}=-2.2\right)$. All $\varepsilon_{\mathrm{Nd}}$ are negative, and do not present significative variations with rock type or rock chemistry (tabl. I). These very homogeneous values suggest that these lavas are cogenetic, and indicate a crustal signature in

the melting source. The ${ }^{87} \mathrm{Sr} /{ }^{86} \mathrm{Sr}$ ratio is less homogeneous and ranges between 0.71128 and $0.70415 ; \varepsilon_{\mathrm{Sr}}$ ranges from 0 to 325 (tabl. I). As exposed above, $\mathrm{Rb}$ and $\mathrm{Sr}$ mobility during 
hydrothermalism and alteration precludes any use of these elements as markers of the magmatic sources.

\section{Discussion}

\section{$\underline{\text { Geochemistry }}$}

Whatever their location or petrology, all the analysed samples display high $(\mathrm{La} / \mathrm{Yb})_{\mathrm{n}}$ ratios but almost flat HREE patterns, marked negative Eu anomalies, homogeneous negative $\varepsilon_{\mathrm{Nd}}$ values (between -5.8 and -3.9) and in primitive mantle-normalized plots, negative $\mathrm{Nb}, \mathrm{Ta}, \mathrm{P}$, $\mathrm{Sm}, \mathrm{Ti}$ anomalies and positive $\mathrm{Th}, \mathrm{U}$ and $\mathrm{Pb}$ anomalies. The most $\mathrm{SiO}_{2}$-rich and $\mathrm{MgO}$-poor rocks and one basalt (CLB95-17) can be distinguished from other samples by a negative correlation in $\mathrm{Ti} / \mathrm{Zr}$ diagram (figs. $2 \& 3$ ). These samples present additional geochemical characteristics, such as $\mathrm{Y}$ depletion and enhanced negative $\mathrm{Ti}$ anomalies, and for some samples negative Ce anomalies.

The occurence of mafic rocks implies partial melting of the mantle. As the most SiO2-rich rocks display REE spectrums that are less enriched in LREE than mafic rocks, they can not be linked together only by crystal fractionation processes. However, as they present similar characteristics, all these lavas may have been formed from similar sources and similar mechanisms. All these rocks belong to a shoshonitic suite, characterized by the absence of Ti and Fe enrichment during crystal fractionation. This is a classical feature of hydrous melts [Gill, 1981]. Similarly, as $\mathrm{Nb}$ and $\mathrm{Ta}$ are insoluble in water, their negative anomalies in primitive mantle-normalized plots can also result from a mantle source metasomatised by water.

As shown by the occurence of sedimentary xenoliths in these lavas, the positive $U$, Th and $\mathrm{Pb}$ anomalies may be explained by contamination by continental crust, while the negative $\mathrm{Ce}$ 
anomaly may indicate contamination by oceanic rocks (sediments or altered oceanic crust) [Bohrson and Reid, 1997]. These contaminations may occur during magma ascent, but more probably reflect the direct contribution of hydrous crustal materials to mantle melting, as suggested by the negative $\varepsilon_{\mathrm{Nd}}$ values, the homogeneous shape of REE patterns, and the Ti/Y versus $\mathrm{Zr} / \mathrm{Y}$ and $\mathrm{Nb} / \mathrm{La}$ versus $\mathrm{Th} / \mathrm{La}$ diagrams (Fig. 7). All samples display a positive linear trend, except one basalt (CLB95-17) in both diagrams and the most $\mathrm{SiO}_{2}$-rich rocks in $\mathrm{Ti} / \mathrm{Y}$ versus $\mathrm{Zr} / \mathrm{Y}$ diagram. This suggests that the contamination by hydrous crustal material is strictly linked to melting of the source, i.e. that the mantle protolith was metasomatised by hydrous crustal materials, that participated in its melting. Among the analysed rocks, the Decazeville acidic lavas have the highest $\mathrm{Ti} / \mathrm{Y}, \mathrm{Zr} / \mathrm{Y}, \mathrm{Nb} / \mathrm{La}$ and $\mathrm{Th} / \mathrm{La}$ ratios, suggesting that the proportion of crustal material was higher in the source of these volcanic rocks than for Figeac and Lacapelle-Marival magmas.

Initial fractionation of apatite from these melts can explain the $\mathrm{P}$ negative anomalies. Similarly, the negative anomalies in $\mathrm{Ti}, \mathrm{Eu}$ and $\mathrm{Y}$ can be explained by early fractionation of Fe-Ti oxides (sometimes found as inclusions in the phenocrysts), plagioclase and clinopyroxenes, respectively. The peculiar Y depletion in the $\mathrm{SiO}_{2}$-rich lavas and CLB95-17 basalt can be explained by clinopyroxene or amphibole fractionation, that may have not occured for the other lavas. Similarly, their negative Ti/Zr correlation can indicate Fe-Ti oxide fractionation.

\section{$\underline{\text { Structural control on magmatism }}$}

Despite differences in structural setting, there are no marked differences in the petrology or geochemistry of rocks from Decazeville, Figeac and Lacapelle-Marival basins. Thus, the faults and the tectonic regime control the formation of these Stephanian basins, where the 
volcanism took place, but they do not influence its petrology or geochemistry. The NW-SE striking dikes found in the basement of Lacapelle-Marival basin, and the occurence of volcanism as the first infilling of all the basins along the Sillon Houiller fault indicate a strikeslip tectonic regime at the French Massif central scale, with a NE-SW stretching direction and a NW-SE shortening direction. This regime is associated to the left-lateral slip on the Sillon Houiller fault, and to extension or right-lateral transtension along the Argentat fault. This seems to be the main tectonic regime at the time of the infilling of the Stephanian basins along these faults [Basile, 2006]. As the same volcanism systematically occurred in all the basins along the Sillon Houiller fault [Letourneur, 1953], it can be proposed that the LacapelleMarival volcanism, located only $25 \mathrm{~km}$ West of the Sillon Houiller fault, came from the same source as the Decazeville volcanism. The local variations in the tectonic regime only controlled the volume and surface covered by volcanic lava flows.

\section{$\underline{\text { Late-orogenic Variscan magmatism }}$}

Stephanian volcanism from the French Massif central belongs to the extended K-rich igneous province emplaced during Stephanian to Early Permian times in the southern part of the European Variscan belt [Pyrénées: Innocent et al., 1994; Western Alps: Cannic et al., 2002; Central Alps: Schaltegger et al., 1991; Southern Alps: Rottura et al., 1998, Cortesogno et al., 1998; Corsica and Sardinia: Tommasini et al., 1995]. In the Pyrénées [Bixel and Lucas, 1983] and Western Alps [Capuzzo and Bussy, 2000], this volcanism is located in basins clearly controlled by strike-slip faults. Together with the K-rich character, these igneous provinces share similar geochemical patterns with the Stephanian volcanism for the SW Massif central: in chondrite-normalized diagrams, LREE-enriched patterns, flat HREE spectra and negative $\mathrm{Eu}$ anomalies; in primitive mantle normalized diagrams, negative $\mathrm{Nb}$, $\mathrm{Ta}$ and $\mathrm{Ti}$ anomalies, and positive Th and $U$ anomalies; and negative $\varepsilon_{\mathrm{Nd}}$ values ( -3 to -7 ), with the 
exception of the most recent (Permian) lava that have slightly positive $\varepsilon_{\mathrm{Nd}}$ values [Innocent $e t$ al., 1994; Rottura et al., 1998; Cannic et al., 2002;]. It is noteworthy that these geochemical characteristics were homegeneous during a large time span and in various parts of the Variscan belt.

The origin of potassic late-orogenic magmatism is still a matter of debate [Gibson et al., 1993; Liégeois et al., 1998; Miller et al., 1999; Pecerillo and Martinotti, 2006].

- As this magmatism indicates a hydrous melt, some authors [e.g. Stampfli, 1996] proposed that it was generated in an active subduction or back-arc setting. However no subduction was active in this part of the Variscan belt at that time, the studied Stephanian volcanism can therefore not be directly linked to subduction processes.

- More frequently, the geochemical patterns of potassic late-orogenic magmatism have been explained by contamination, either by crustal contamination during magma ascent, or more probably by mantle metasomatism before melting, as indicated by the systematic and homogeneous character of contamination. Up to now, this metasomatism has been considered to be inherited from a suprasubduction position, either in the same orogenic cycle, or during previous subductions [e.g. Miller et al., 1999].

The southern part of the Variscan orogeny results from continental collision following a northward subduction, whose remnants are found in the French Massif central [Matte, 1986, 2001]. However, the southernmost part of the French Massif central as well as the Pyrénées belong to the subducting plate, and its underlying mantle was not in a suprasubduction position, and could not be metasomatised by a Variscan subduction. However, this does not exclude older (Precambrian) metasomatism processes.

If the mantle was previously metasomatised, the main mechanism proposed to explain its melting in a post-orogenic setting is lithospheric thinning, inducing mantle decompression [e.g. Gibson et al., 1993; Innocent et al., 1994; Rottura et al., 1998]. However, the Stephanian 
volcanism occurred in a strike-slip tectonic regime in the French Massif central, and before the main Permian extension that ended the variscan orogenic cycle [Ménard and Molnar, 1988].

- We propose an alternative mechanism, controlled by lithospheric-scale strike-slip faulting, to explain both mantle metasomatism and mantle melting generating the potassic late-orogenic volcanism. At the end of the orogeny, the various parts of the mountain belt differ by their crustal and lithospheric thicknesses, thermal gradients, rock nature and geological history. As observed in the Ivrea body, hydrous metasediments can occur in the lower crust at the end of the Variscan orogeny [Harlov and Forster, 2002].

As the late-orogenic strike-slip faults cross the orogenic zonation with some tens or hundreds kilometres of horizontal slipping, these bring into contact different parts of the mountain belt. For example, this horizontal displacement can bring into contact, and at the same depth, mantle materials on one side and lower crust, including still hydrated metasediments, on the other. The crustal fluids could then locally hydrate the adjacent mantle, and this metasomatism may induce mantle melting. The resulting magmas have geochemical patterns that indicate contamination by continental crust.

In this hypothetical mechanism, mantle metasomatism is not inherited from a previous suprasubduction zone, but is acquired by horizontal fluid transfer in or across lithosphericscale strike-slip faults. Consequently, mantle melting can occur without vertical displacements and adiabatic decompression, since metasomatism controlled by strike-slip faults drastically decreases its solidus temperature. Because fluid transfers across strike-slip faults and induced mantle metasomatism are only local and can occur only once, this mechanism can explain why this late-orogenic potassic magmatism represents small volumes of lava, and why it happens only at the beginning of late-orogenic strike-slip faulting. 


\section{Acknowledgements}

D. Arnaud, F. Senebier and F. Coeur are thanked for sample preparation, F. Keller and L. Briqueu for the chemical analyses, F. Chauvet for helpfull discussions. We are particularly grateful to A. Demant and M. Faure for their reviews and comments, and to J. Allibon for his english tips and corrections. This work has been funded by the LGCA.

\section{References}

Barrat J.A., Keller F., Amosse J., TAYlor R.N., Nesbitt R.W. \& Hirata T. (1996). Determination of rare earth elements in sixteen silicate reference samples by ICP-MS after Tm addition and ion exchange separation. - Geost. Newsletter, 32, 133-139.

BASILE C. (2006). - A new interpretation of Stephanian deformation in the Decazeville basin (Massif central, France): consequences on late Variscan tectonism. - Int. J. Earth Sci., 95, 791-801.

Beccaluva L., Bianchini G., Bonadiman C., Siena F. \& Vaccaro C. (2004). - Coexisting anorogenic and subduction-related metasomatism in mantle xenoliths from the Betic Cordillera (southern Spain). - Lithos, 75, 67-87.

BiXel F. \& LuCAS C. (1983). - Magmatisme, tectonique et sédimentation dans les fossés stéphano-permiens des Pyrénées occidentales. - Rev. Géol. Dyn. Géogr. Phys., 24, 329-342.

Bles J.L., Bonijoly D., Castaing C. \& Gros Y. (1989). - Successive post-Variscan stress fields in the French Massif central and its border (Western European plate): comparison with geodynamic data. - Tectonophysics, 169, 79-111. 
BonIN B. (2004). - Do coeval mafic and felsic magmas in post-collisional to within-plate regimes necessarily imply two constrasting, mantle and crustal, sources? A review. Lithos, 78, 1-24.

BOHRSON W.A. \& REID M.R. (1997). - Genesis of silicic peralkaline rocks in an ocean island setting by crustal melting and open-system processes: Socorro Island, Mexico. $-J$. Petrol., 38, 1137-1166.

Bruguier O., Becq-Giraudon J.F., Bosch D. \& Lancelot J.R. (1998). - Late Visean hidden basins in the internal zones of the variscan belt: $\mathrm{U}-\mathrm{Pb}$ zircon evidence from the French Massif central. - Geology, 26, 627-630.

Burg J., BRUn J.P. \& VAN DEN DRIESSChE J. (1990). - Le Sillon houiller du Massif central français: faille de transfert pendant l'amincissement crustal de la chaîne varisque?- $C$. R. Acad. Sci. Paris, 311, 147-152.

Cannic S., Lapierre H., Monie P., Briqueu L. \& Basile C. (2002). - Late orogenic evolution of the Variscan lithosphere: Nd isotopic constraints from the western Alps. Schweiz. Mineral. Petrogr. Mitt., 82, 77-99.

CApuzzo N. \& Bussy F. (2000). - High-precision dating and origin of synsedimentary volcanism in the Late Carboniferous Salvan-Dorenaz basin (Aiguilles Rouges Massif, Western Alps). - Schweiz. Mineral. Petrogr. Mitt., 80, 147-167.

Cortesogno L., Cassinis G., Dallagiovanna G., Gaggero L., Oggiano G., Ronchi A., Seno S. \& VAnOssi M. (1998). - The Variscan post-collisional volcanism in Late Carboniferous-Permian sequences of Ligurian Alps, Southern Alps and Sardinia (Italy): a synthesis. - Lithos, 45, 305-328.

FAURE M. (1995). - Late orogenic carboniferous extensions in the Variscan French Massif central. - Tectonics, 14, 132-153. 
Feix I., Guillot P.L., Miyashita S., Bossiere G. \& Floc'H J.P. (1987). - Arguments en faveur d'un épisode majeur en cisaillement dextre le long de la faille d'Argentat (Massif central). Conséquences. - C. R. Acad. Sci. Paris, 305, 473-476.

Genna A., Roig J.Y., Debriette P.J. \& Bouchot V. (1998). - Le bassin houiller d'Argentat (Massif central français), conséquence topographique d'un plissement de son substratum varisque. - C. R. Acad. Sci. Paris, 327, 279-284.

Gibson I.L., KirkPATRICK R.J., EMmermann R., SchmincKe H.U., Pritchard G., OAKLey P.J., ThORPE R.S. \& MARRINER G.F. (1982). - The trace-element composition of the lavas and dikes from a 3-km vertical section through the lava pile of eastern Iceland. J. Geophys. Res., 87, 6532-6546.

Gibson S.A., Thompson R.N., Leat P.T., Morrison M.A., Hendry G.L., Dickin A.P. \& Mitchell J.G. (1993). Ultrapotassic magmas along the flank of the Oligomiocene Rio-Grande rift, USA - Monitors of the zone of lithospheric mantle extension and thinning beneath a continental rift. - J. Petrol., 34, 187-228.

GILL J. (1981). - Orogenic andesites and plate tectonics. - Springer-Verlag, New York, 390 p.

Grolier J. \& Letourneur J. (1968). - L'évolution tectonique du grand Sillon houiller du Massif central français. - XXIIIème Congrès Géologique International, 1, 107-116.

HARLOV D.E. \& FORSTER H.J. (2002). - High-grade fluid metasomatism on both a local and a regional scale: the Seward Peninsula, Alaska, and the Val Strona di Omagna, IvreaVerbano zone, norther, Italy. Part I: Petrography and silicate mineral chemistry. $-J$. Petrol., 45, 769-799.

InNocent C., BRiqueu L. \& CABANis B. (1994). - Sr-Nd isotope and trace-element geochemistry of late Variscan volcanism in the Pyrénées: magmatism in post-orogenic extension?- Tectonophysics, 238 161-181. 
KEPPLER H. (1996). - Constraints from partitioning experiments on the composition of subduction-zone fluids. - Nature, 380, 237-240.

LapierRe H., Dupuis V., DE Lepinay B.M., TARdy M., Ruiz J., Maury R.C., Hernandez J. \& LoubeT M. (1997). - Is the lower Duarte Igneous Complex (Hispaniola) a remnant of the Caribbean plume-generated oceanic plateau?- J. Geol., 105, 111-120.

Lefavrais-Raymond A., AstruC J.G., Guillot P.L., Bonijoly D., Lefavrais-HenRy M. \& Marandat B. (1990). - Notice explicative, Carte géol. France (1/50 000), feuille Figeac (858). - Orléans, Bureau de Recherches Géologiques et Minières, 92 p.

Letourneur J. (1953). - Le grand Sillon houiller du Plateau Central français. - Bull. Serv. Carte Géologique de la France, 51, 1-236.

Liegeois J.P., Navez J., Hertogen J. \& Black R. (1998). - Constrasting origin of postcollisional high-K calc-alkaline and shoshonitic versus alkaline and peralkaline granitoids. The use of sliding normalization. - Lithos, 45, 1-28.

MARIGNAC C. \& CUNEY M. (1999). - Ore deposits of the French Massif central: insight into the metallogenesis of the Variscan collision belt. - Min. Depos., 34, 472-504.

MAtTE P. (1986). - La chaîne varisque parmi les chaînes paléozoïques péri atlantiques, modèle d'évolution et position des grands blocs continentaux au Permo-Carbonifère. Bull. Soc. géol. France, 8, 9-24.

Matte P. (2001). - The Variscan collage and orogeny (480-290 Ma) and the tectonic definition of the Armorica microplate: a review. - Terra Nova, 13, 122-128.

Menard G. \& Molnar P. (1988). - Collapse of a Hercynian Tibetan plateau into a late Paleozoic European basin and range province. - Nature, 334, 235-237. 
Miller C., Schuster R., Klötzli U., Frank W. \& Purtscheller F. (1999). - Postcollisional potassic and ultrapotassic magmatism in SW Tibet: geochemical and Sr$\mathrm{Nd}-\mathrm{Pb}-\mathrm{O}$ isotopic constraints for mantle source characteristics and petrogenesis. $-J$. Petrol., 40, 1399-1424.

Morimoto N., FAbries J., Ferguson A.K., GinZburg I.V., Ross M., Seifert F.A, Zussman J., Aoki K. \& GotTardi G. (1988). - Nomenclature of pyroxenes. - Amer. Min., 73, 1123-1133.

MORRE N. (1966). - Etude pétrographique sur les roches volcaniques carbonifères de la région de Figeac. - Bull. Soc. Geol. Fr., 7, 8, 322-328.

Morre N. \& Quesnel G. (1967). - Etude pétrographique sur les roches volcaniques carbonifères de Lacapelle-Marival. - C. R. Somm. Soc. Géol. Fr., 4, 160-161.

MÜLleR D., Rock N.M.S \& GROVES D.I. (1992). - Geochemical discrimination between shoshonitic and potassic volcanic rocks in different tectonic settings: a pilot study. Mineral. Petrol., 46, 259-289.

Peccerillo A. \& MARTinOtTi G. (2006). - The Western Mediterranean lamproitic magmatism: origin and geodynamic significance. - Terra Nova, 18, 109-117.

Roig J.Y., CAlcagno P., Bouchot V., Maluski H. \& Faure M. (1997). - Modélisation 3D du paléochamp hydrothermal As + Au (330-300 Ma) le long de la faille d'Argentat (Massif central français). - Chron. Rech. Min., 528, 63-69.

Rottura A., Bargossi G.M., Caggianelli A., Del Moro A., Visona D. \& Tranne C.A. (1998). - Origin and significance of the Permian high-K calc-alkaline magmatism in the central-eastern Southern Alps, Italy. - Lithos, 45, 329-348. 
SchaltegGer U., Gnos E., KÜPFER T. \& LABhart T.P. (1991). - Geochemistry and tectonic significance of Late Hercynian potassic and ultrapotassic magmatism in the Aar massif (Central Alps). - Schweiz. Mineral. Petrogr. Mitt., 71, 391-403.

STAMPfli G. (1996). - The Intra-Alpine terrain: a paleo-tethyan remnant in the Alpine Variscides. - Eclogae Geol. Helv., 89, 13-42.

Sun S.S. \& MCDONOUGH W.F. (1989). - Chemical and isotopic systematics of oceanic basalts: implications for mantle composition and processes. - In: Saunder A.D. \& Norry M.J. Eds, Magmatism in the ocean basin, Geol. Soc. London Spec. Pub., 42, 313-345.

TATSUMI Y. \& KoGISO T. (1997). - Trace element transport during dehydration processes in the subducted oceanic crust: 2 . Origin of chemical and physical characteristics in arc magmatism. - Earth Planet. Sci. Lett., 148, 207-221.

Tommasini S., Poli G. \& Halliday A.N. (1995). - The role of sediment subduction and crustal growth in Hercynian plutonism: isotopic and trace element evidence from the Sardinia-Corsica batholith. - J. Petrol., 36, 1305-1332.

VETTER P. (1968). - Géologie et paléontologie des bassins houillers de Decazeville, de Figeac et du détroit de Rodez. - Houillères du Bassin d'Aquitaine, Albi, 1-637.

WinCHESTER J.A. \& Floyd P.A. (1977). - Geochemical discrimination of different magma series and their differentiation products using immobile elements. - Chem. Geol., 20, $325-343$. 


\section{Figure Captions}

Figure 1: Schematic geologic map of the area between Lacapelle-Marival and Decazeville basins. Analysed samples are located. A: Schematic geologic map of the French Massif central [from Basile, 2006]. B: Synthetic lithostratigraphic column of the Decazeville basin [from Basile, 2006].

Figure 1: Carte géologique schématique de la région comprise entre les bassins de Lacapelle-Marival et Decazeville, avec la localisation des échantillons analysés. A: Carte géologique schématique du Massif central français [d'après Basile, 2006]. B: Colonne lithostratigraphique synthétique du bassin de Decazeville [d'après Basile, 2006].

Figure 2: Variations of minor- $\left(\mathrm{TiO}_{2}\right)$ and trace-elements (Th, U, Nb, $\mathrm{La}, \mathrm{Pb}, \mathrm{Rb}, \mathrm{Sr}, \mathrm{Y}$ ) versus Zr. The symbols indicate the sample location (cf. Fig. 1).

Figure 2: Variations des teneurs en éléments mineur $\left(\mathrm{TiO}_{2}\right)$ et traces (Th, $\mathrm{U}, \mathrm{Nb}, \mathrm{La}, \mathrm{Pb}$, $R b, S r, Y)$ par rapport au Zr. Les symboles correspondent à la localité d'échantillonage (cf. Fig. 1).

Figure 3: $\mathrm{Zr} / \mathrm{Ti}$ versus $\mathrm{Nb} / \mathrm{Y}$ discrimination diagram [Winchester and Floyd, 1977].

Figure 3: Diagramme discriminant Zr/Ti par rapport à $N b / Y$ [Winchester and Floyd, 1977].

Figure 4: Th/Yb versus Ta/Yb discrimination diagram [Müller et al., 1992].

Figure 4: Diagramme discriminant Th/Yb par rapport à Ta/Yb [Müller et al., 1992].

Figure 5: Chondrite-normalized rare earth elements patterns [Sun and McDonough, 1989]. Sample sets as a function of location (cf. Fig. 1).

Figure 5: Spectres de terres rares normalisés aux chondrites [Sun and McDonough, 1989]. Les échantillons sont regroupés en fonction de leur localisation (cf. Fig. 1). 
Figure 6: Primitive mantle-normalized spidergrams [Sun and McDonough, 1989]. Sample sets as a function of location (cf. Fig. 1).

Figure 6: Spidergrams normalisés au manteau primitif [Sun and McDonough, 1989]. Les échantillons sont regroupés en fonction de leur localisation (cf. Fig. 1).

Figure 7: Variations of $\mathrm{Ti} / \mathrm{Y}$ versus $\mathrm{Zr} / \mathrm{Y}$ (left) and $\mathrm{Nb} / \mathrm{La}$ versus $\mathrm{Th} / \mathrm{La}$ (right). The symbols indicate the sample location (cf. Fig. 1).

Figure 7: Variations des rapports Ti/Y en fonction de $\mathrm{Zr} / \mathrm{Y}$ (à gauche) et $\mathrm{Nb} / \mathrm{La}$ en fonction de Th/La (à droite). Les symboles indiquent la localisation des échantillons (cf. Fig. 1).

\section{Table Captions}

Table I: Major- and trace-element analyses, ${ }^{87} \mathrm{Sr} /{ }^{86} \mathrm{Sr}$ and ${ }^{143} \mathrm{Nd} /{ }^{144} \mathrm{Nd}$ isotope ratios for studied samples. Major oxides are in wt\%, Trace-elements are in ppm. $\mathrm{Fe}_{2} \mathrm{O}_{3}$ : total iron as ferric oxide; LOI: loss on ignition; bdl: below detection limit; nd: not determined. Rock types are given from figure 3. Location on figure 1 (LM for Lacapelle-Marival).

Table I: Analyses chimiques en éléments majeurs et traces, rapports isotopiques en ${ }^{87} \mathrm{Sr}{ }^{86} \mathrm{Sr}$ et ${ }^{143} \mathrm{Nd}{ }^{144} \mathrm{Nd}$ pour les échantillons étudiés. Les éléments majeurs sont donnés en \%, les éléments traces en ppm. $\mathrm{Fe}_{2} \mathrm{O}_{3}$ : Fer total; LOI: perte au feu; bdl: sous le seuil de detection; nd: non déterminé. La terminologie des laves est déduite de la figure 3. Localisation sur la figure 1 (LM: Lacapelle-Marival). 


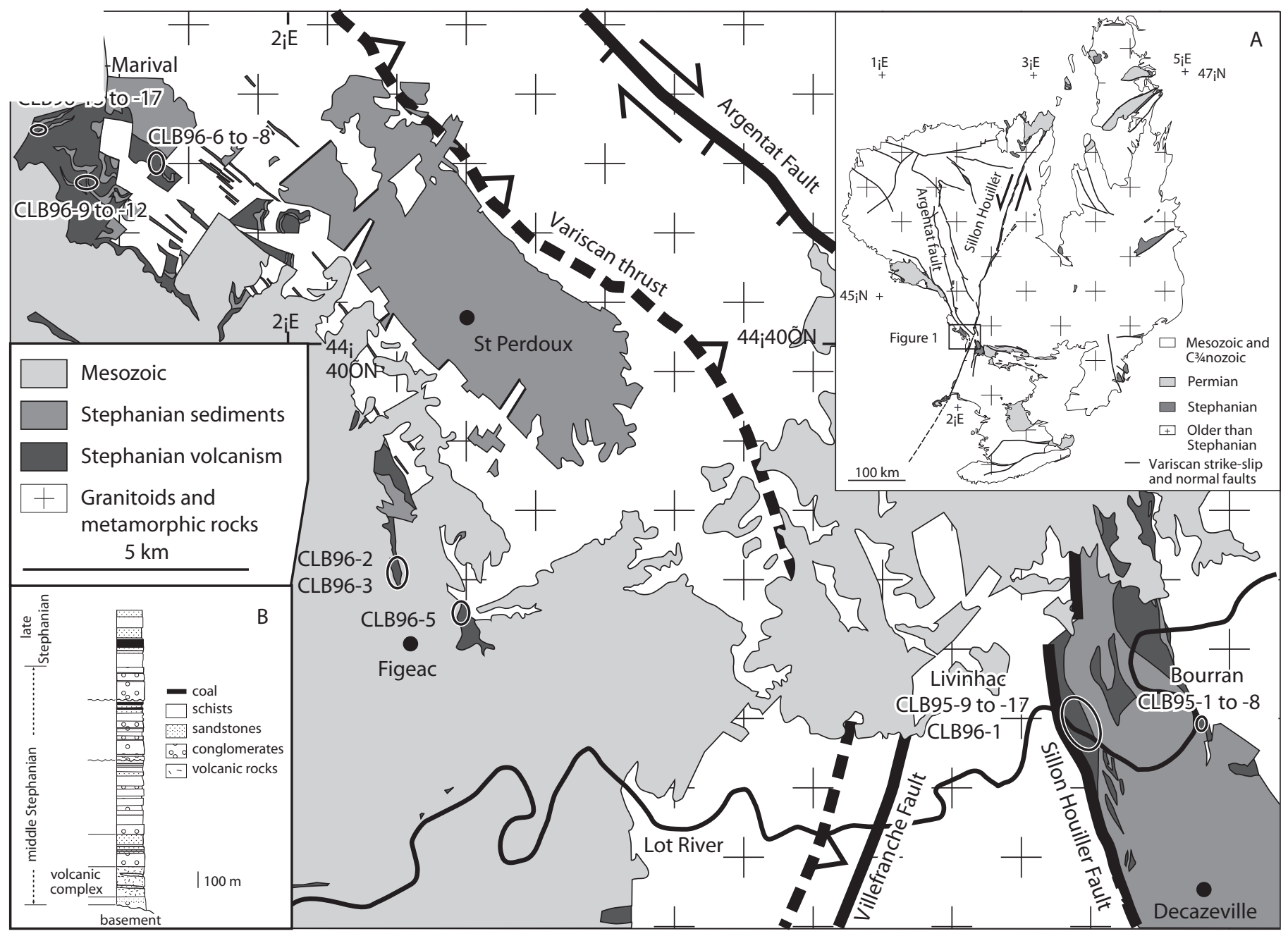


Figure 2
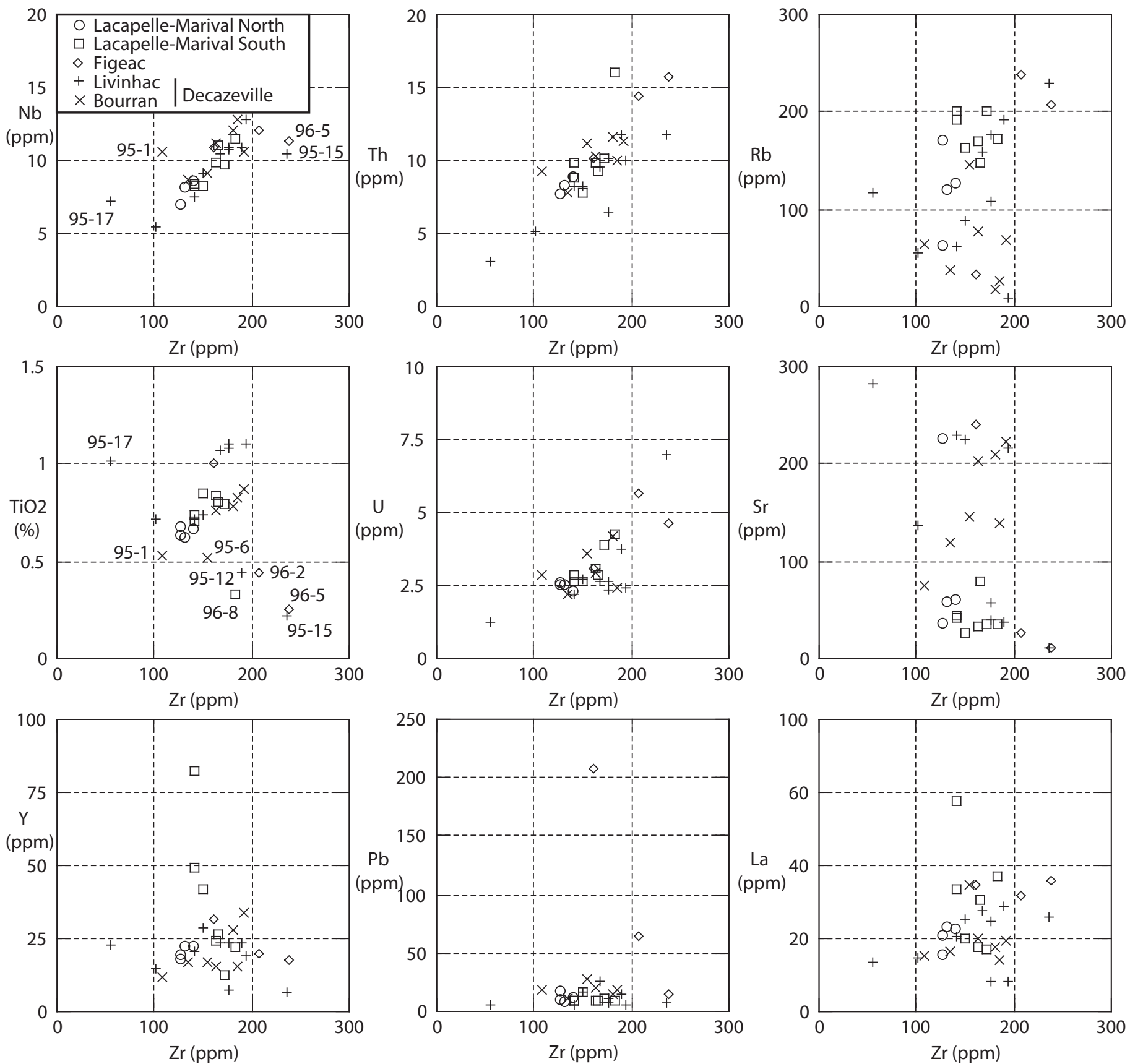
Figure 3

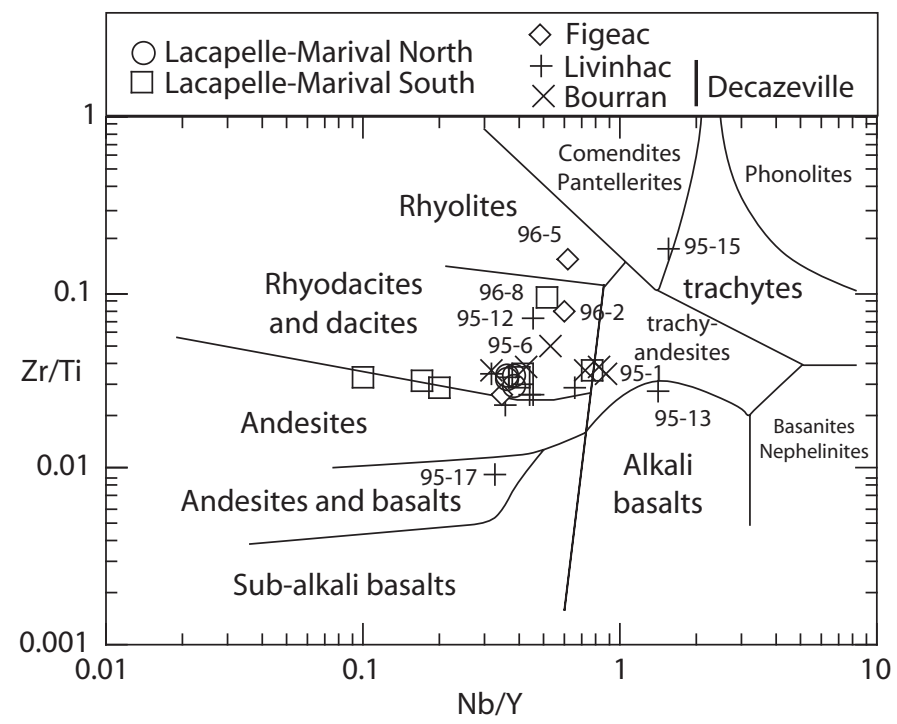


Figure 4

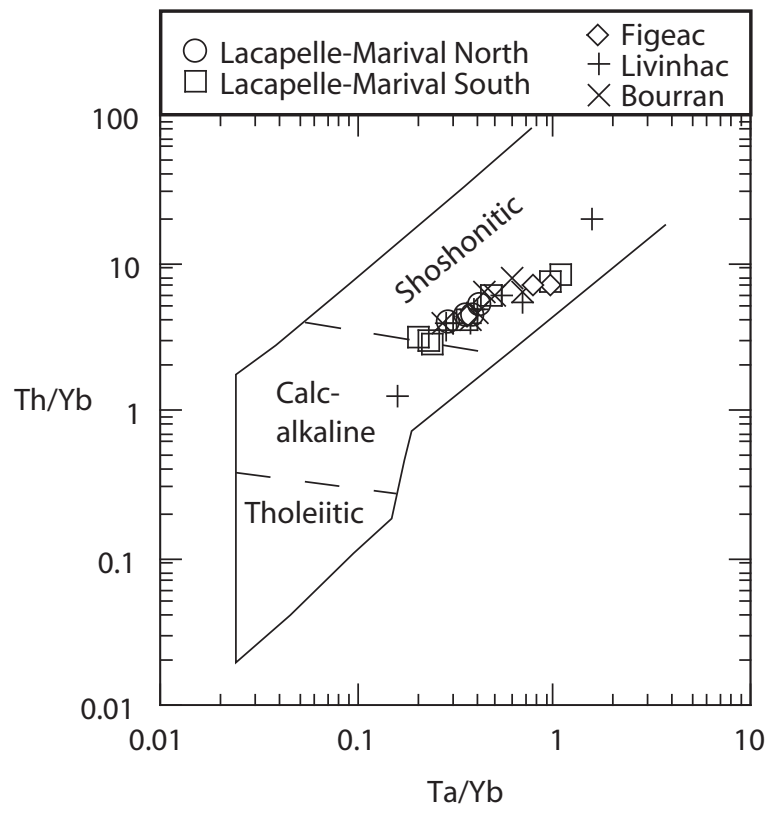


Figure 5
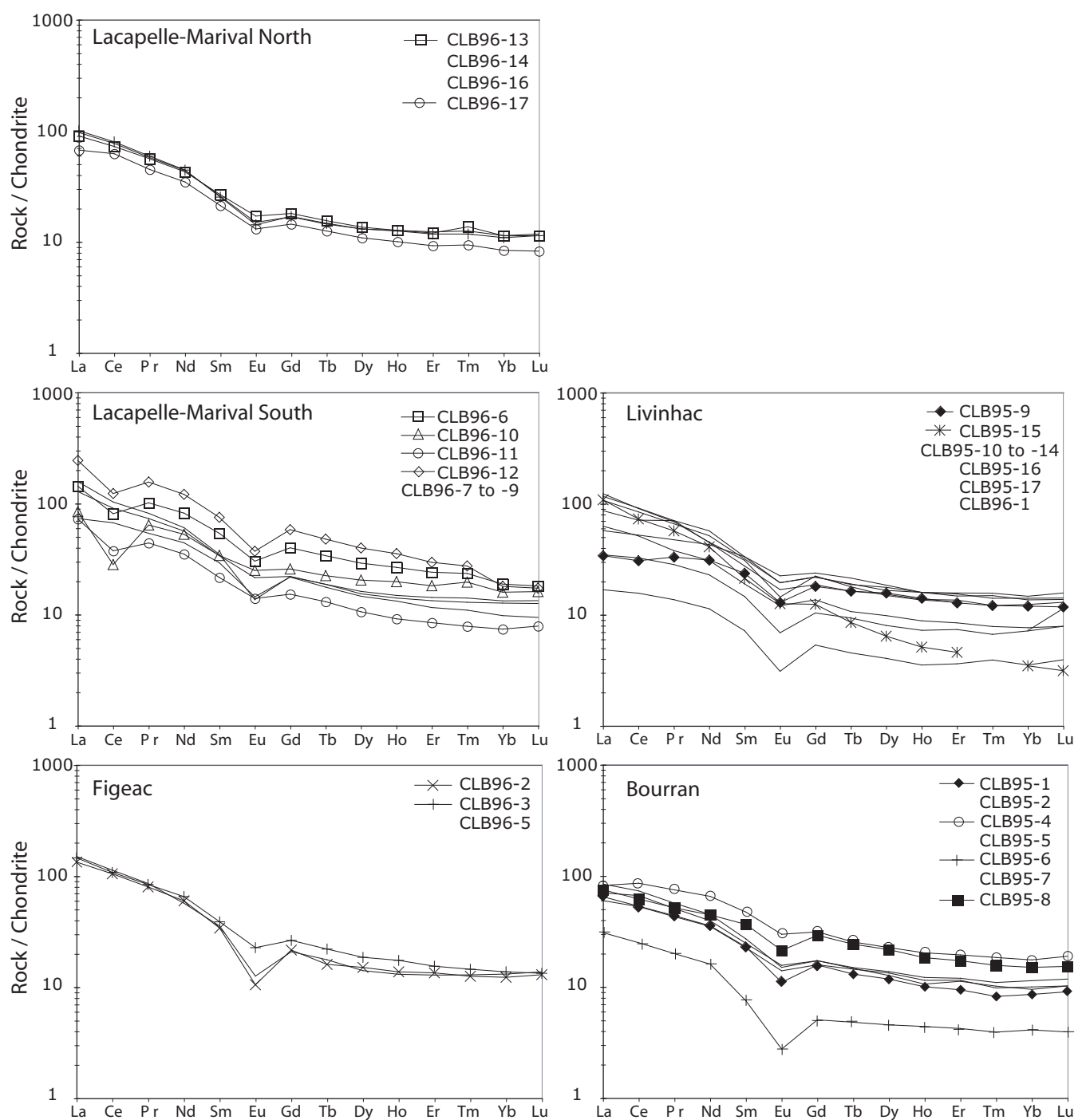

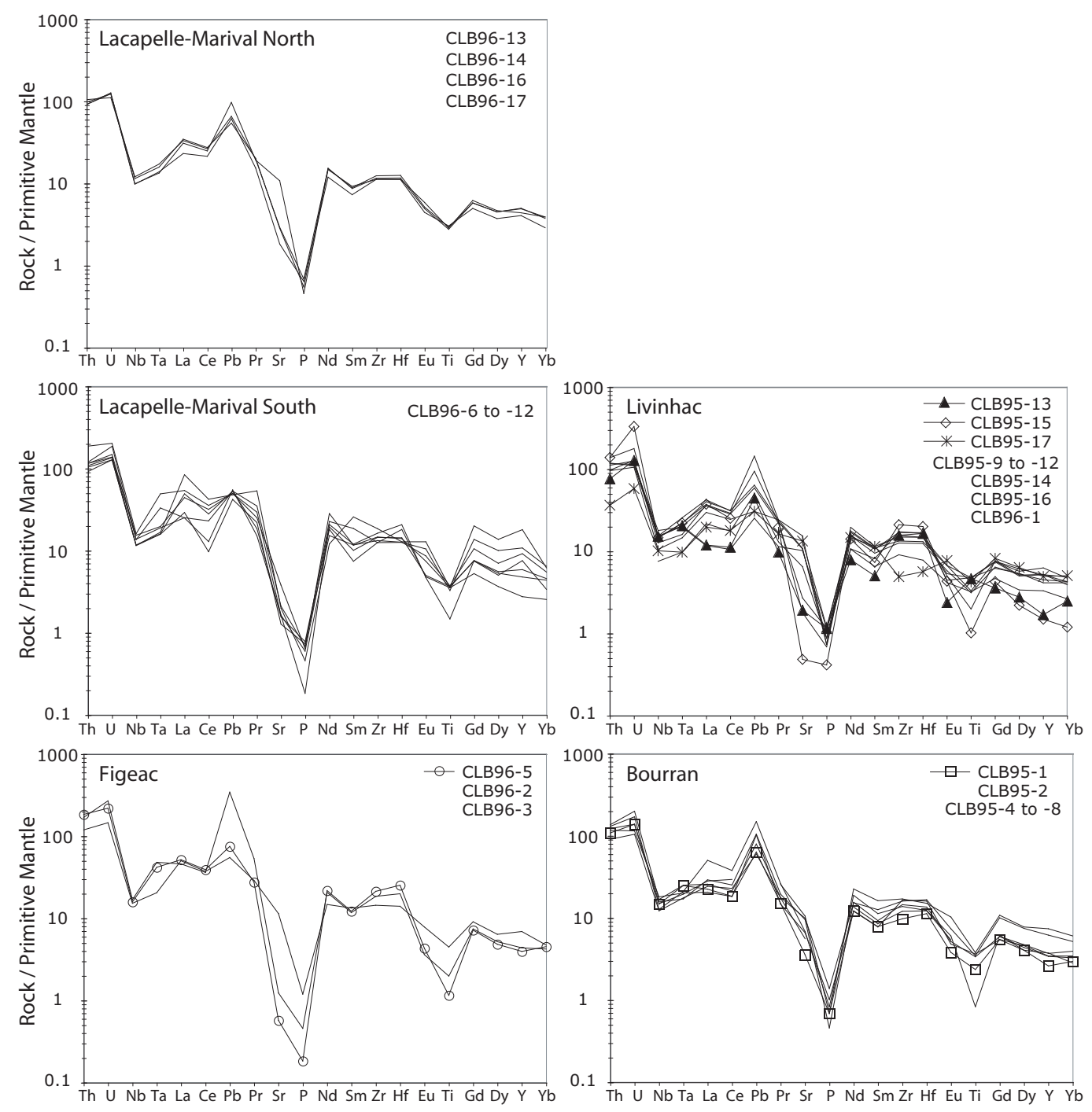
Figure 7
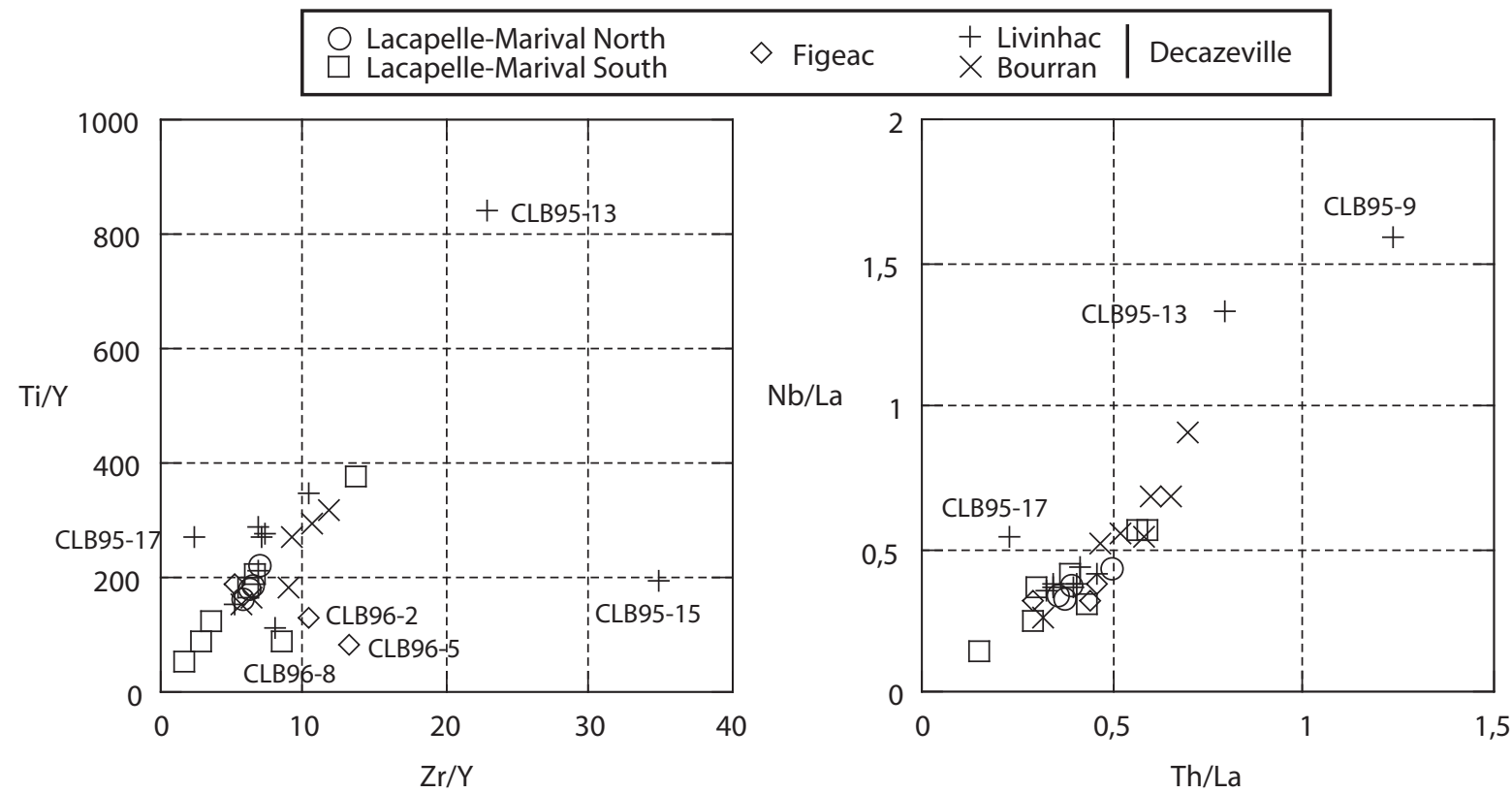


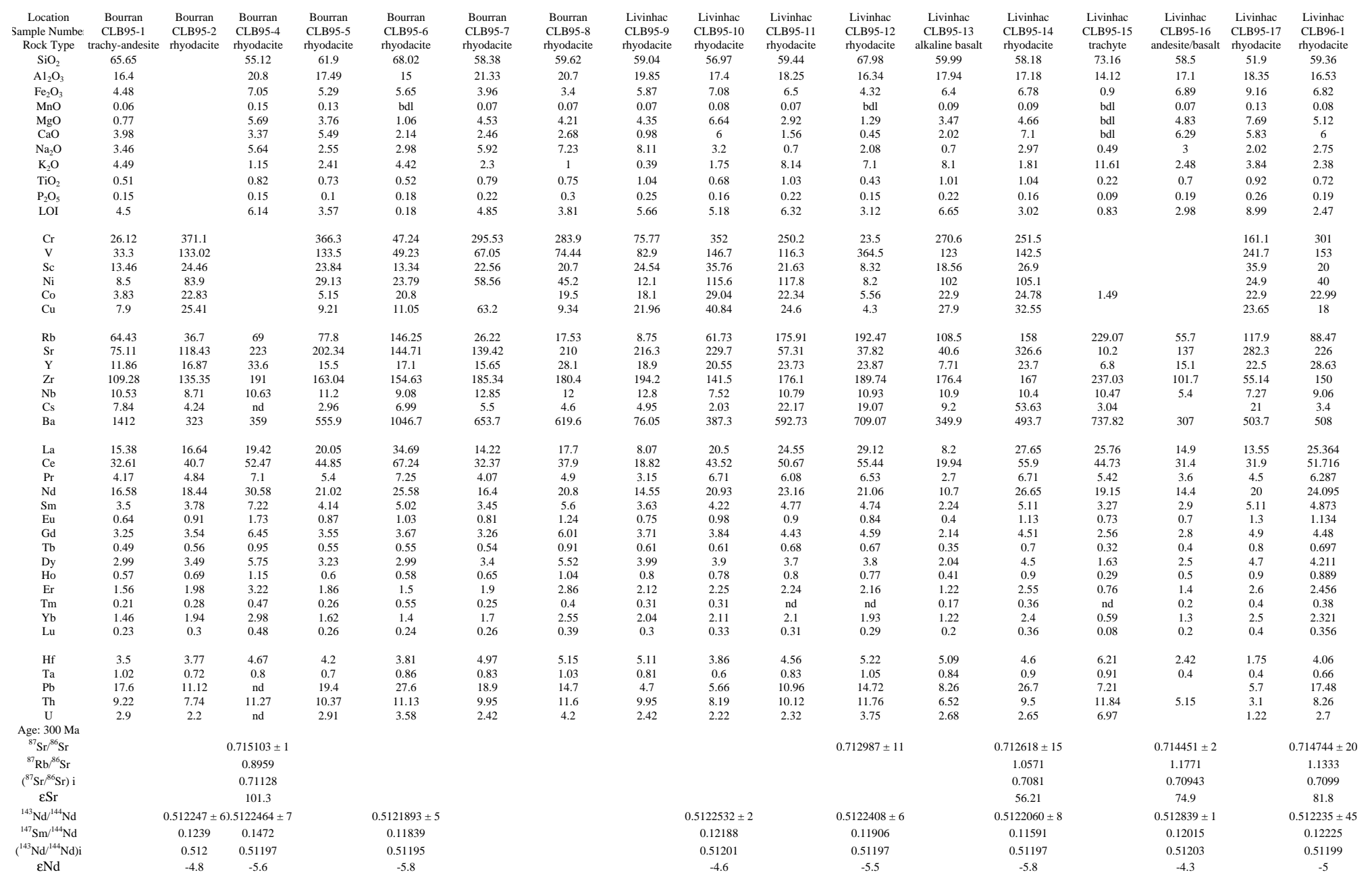




\begin{tabular}{|c|c|c|c|c|c|c|c|c|c|c|c|c|c|c|}
\hline $\begin{array}{l}\text { Location } \\
\text { Sample number }\end{array}$ & $\begin{array}{l}\text { Figeac } \\
\text { CLBB6-2 }\end{array}$ & $\begin{array}{l}\text { Figeac } \\
\text { CLBB66-3 }\end{array}$ & $\begin{array}{l}\text { Figeac } \\
\text { CLBB6-5 }\end{array}$ & $\begin{array}{l}\text { LM South } \\
\text { CLBB66-6 }\end{array}$ & $\begin{array}{l}\text { LM South } \\
\text { CLBB6-7 }\end{array}$ & $\begin{array}{l}\text { LM South } \\
\text { CLBB6-8 }\end{array}$ & $\begin{array}{l}\text { LM South } \\
\text { CLBB6-9 }\end{array}$ & $\begin{array}{l}\text { LM South } \\
\text { CBB96-10 }\end{array}$ & $\begin{array}{l}\text { LM South } \\
\text { CBB96-11 }\end{array}$ & $\begin{array}{l}\text { LM South } \\
\text { CLB96-12 }\end{array}$ & $\begin{array}{l}\text { LM North } \\
\text { CL996-13 }\end{array}$ & $\begin{array}{l}\text { LM North } \\
\text { CBM96-14 }\end{array}$ & $\begin{array}{l}\text { LM North } \\
\text { CLPB66-16 }\end{array}$ & $\begin{array}{l}\text { LM North } \\
\text { CLP96-17 }\end{array}$ \\
\hline Rock Type & rhyodacite & rhyodacite & rhyolite & & & & & rhyodacite & rhyodacite & & rhyodacite & & & rhyodacitit \\
\hline $\mathrm{SiO}_{2}$ & 70.55 & 61.3 & 73.95 & 60.08 & 61.29 & 71.91 & 57.05 & 58.96 & 60.31 & 65.51 & 58.14 & 52.82 & 60.79 & 58.99 \\
\hline $\mathrm{Al}_{2} \mathrm{O}_{3}$ & 15.96 & 17.6 & 14.46 & 17.61 & 17.58 & 15.02 & 18.88 & 17.46 & 17.82 & 17.78 & 16.48 & 16.46 & 15.77 & 16.56 \\
\hline $\begin{array}{l}\mathrm{Fe}_{2} \mathrm{O}_{3} \\
\mathrm{MnO}\end{array}$ & $\begin{array}{l}1.79 \\
0.01\end{array}$ & $\begin{array}{l}6.31 \\
0.05\end{array}$ & 1.11 & $\begin{array}{l}6.6 \\
0.04\end{array}$ & $\begin{array}{l}6.22 \\
0.06\end{array}$ & $\begin{array}{l}2.16 \\
0.03\end{array}$ & $\begin{array}{l}5.71 \\
0.76\end{array}$ & 7.21 & 4.48 & 6.93 & 7.09 & 6.24 & 7.55 & 7.17 \\
\hline $\begin{array}{l}\mathrm{MnO} \\
\mathrm{MgO}\end{array}$ & $\begin{array}{l}0.01 \\
0.61\end{array}$ & $\begin{array}{l}0.05 \\
4.02\end{array}$ & 0.33 & $\begin{array}{l}0.04 \\
3.43\end{array}$ & $\begin{array}{l}0.06 \\
3.46\end{array}$ & $\begin{array}{l}0.03 \\
0.57\end{array}$ & $\begin{array}{l}0.06 \\
41\end{array}$ & $\begin{array}{l}0.01 \\
3.82\end{array}$ & $\begin{array}{l}0.03 \\
2\end{array}$ & $\begin{array}{l}0.1 \\
3.03\end{array}$ & 0.07 & 0.05 & 0.06 & 0.02 \\
\hline $\begin{array}{l}\mathrm{MgO} \\
\mathrm{CaO}\end{array}$ & $\begin{array}{l}0.61 \\
0.21\end{array}$ & $\begin{array}{l}4.02 \\
5.45\end{array}$ & $\begin{array}{l}0.33 \\
0.14\end{array}$ & $\begin{array}{l}3.43 \\
0.46\end{array}$ & $\begin{array}{l}3.46 \\
0.43\end{array}$ & $\begin{array}{l}0.57 \\
0.22\end{array}$ & $\begin{array}{l}4.1 \\
1.07\end{array}$ & $\begin{array}{l}3.82 \\
0.31\end{array}$ & $\begin{array}{l}2 \\
0.2\end{array}$ & $\begin{array}{l}3.03 \\
0.3\end{array}$ & $\begin{array}{l}6.18 \\
6.81\end{array}$ & $\begin{array}{l}6.12 \\
0.85\end{array}$ & $\begin{array}{l}7.1 \\
0.87\end{array}$ & $\begin{array}{l}6.13 \\
0.51\end{array}$ \\
\hline $\mathrm{Na}_{2} \mathrm{O}$ & 0.78 & 2.1 & 0.92 & 0.79 & 1.89 & 1.41 & 0.55 & 0.08 & 0.73 & 1.08 & 2.49 & 2.68 & 2.5 & 1.3 \\
\hline $\mathrm{K}_{2} \mathrm{O}$ & 9.54 & 1.83 & 8.82 & 10.1 & 8.03 & 8.29 & 1.16 & 10.32 & 11 & 8.46 & 1.92 & 5.22 & 4.62 & 8.48 \\
\hline $\mathrm{TiO}_{2}$ & 0.43 & 0.97 & 0.25 & 0.71 & 0.78 & 0.32 & 0.8 & 0.81 & 0.77 & 0.68 & 0.62 & 0.64 & 0.6 & 0.66 \\
\hline $\mathrm{P}_{2} \mathrm{O}_{5}$ & 0.1 & 0.26 & 0.04 & 0.15 & 0.14 & 0.04 & 0.17 & 0.16 & 0.13 & 0.14 & 0.14 & 0.15 & 0.12 & 0.14 \\
\hline LOI & 1.74 & 3.14 & 1.45 & 3.51 & 3.59 & 1.98 & 4.14 & 4.38 & 2.8 & 3.97 & 2.37 & 4.97 & 4.81 & 3.81 \\
\hline $\mathrm{Cr}$ & 13.25 & 420 & 10.13 & 450 & 180 & 11.58 & 549 & 462 & 266.48 & 416 & 587 & 224 & 260 & 611 \\
\hline $\mathrm{v}$ & 27.28 & 140 & 23.04 & 179 & 170 & 19.42 & 184 & 164 & 111.53 & 149 & 163 & 132 & 138 & 167 \\
\hline $\begin{array}{l}\mathrm{Sc} \\
\mathrm{Ni}\end{array}$ & $\begin{array}{l}22.43 \\
5.74\end{array}$ & $\begin{array}{l}28 \\
60\end{array}$ & $\begin{array}{l}8.18 \\
732\end{array}$ & $\begin{array}{l}14 \\
59\end{array}$ & $\begin{array}{l}14 \\
30\end{array}$ & $\begin{array}{c}8 \\
475\end{array}$ & $\begin{array}{l}11 \\
59\end{array}$ & $\begin{array}{l}10 \\
93\end{array}$ & $\begin{array}{l}55.98 \\
4233\end{array}$ & $\begin{array}{l}13 \\
74\end{array}$ & $\begin{array}{l}23 \\
100\end{array}$ & $\begin{array}{l}16 \\
35\end{array}$ & $\begin{array}{l}18 \\
34\end{array}$ & 16 \\
\hline $\begin{array}{l}\mathrm{Ni} \\
\mathrm{Co}\end{array}$ & $\begin{array}{l}5.74 \\
4.36\end{array}$ & $\begin{array}{c}60 \\
19.01\end{array}$ & $\begin{array}{l}7.32 \\
1.95 \\
\end{array}$ & $\begin{array}{c}59 \\
20.89\end{array}$ & $\begin{array}{c}30 \\
20.49\end{array}$ & $\begin{array}{l}4.75 \\
2.88\end{array}$ & $\begin{array}{c}59 \\
28.55\end{array}$ & $\begin{array}{l}93 \\
8.85\end{array}$ & $\begin{array}{l}42.33 \\
14.49\end{array}$ & $\begin{array}{c}74 \\
18.23\end{array}$ & 100 & $\begin{array}{c}35 \\
15.89 \\
\end{array}$ & $\begin{array}{c}34 \\
23.37\end{array}$ & $\begin{array}{c}96 \\
2942\end{array}$ \\
\hline $\mathrm{Cu}$ & $\begin{array}{l}\begin{array}{r}4.36 \\
11\end{array} \\
1\end{array}$ & $\begin{array}{l}1.901 \\
14\end{array}$ & $\begin{array}{l}1.95 \\
9.86\end{array}$ & $\begin{array}{c}20.89 \\
21\end{array}$ & ${ }_{23}^{20.99}$ & $\begin{array}{l}2.88 \\
6.36\end{array}$ & $\begin{array}{c}28.53 \\
34\end{array}$ & $\begin{array}{l}8.83 \\
224\end{array}$ & 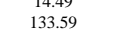 & $\begin{array}{c}18.23 \\
19\end{array}$ & $\begin{array}{l}29 \\
22\end{array}$ & $\begin{array}{l}15.99 \\
15\end{array}$ & $\begin{array}{l}2.31 \\
11\end{array}$ & $\begin{array}{c}29.42 \\
13\end{array}$ \\
\hline $\mathrm{Rb}$ & 238.61 & 32.49 & 207.54 & 192 & 147 & 172.66 & 171 & 163 & 201.25 & 201 & 65 & 127 & 122 & 173 \\
\hline $\begin{array}{l}\mathrm{Sr} \\
\mathrm{Y}\end{array}$ & $\begin{array}{l}26.02 \\
1098\end{array}$ & $\begin{array}{l}241 \\
3154\end{array}$ & $\begin{array}{l}12.07 \\
1708\end{array}$ & $\begin{array}{l}44.59 \\
492\end{array}$ & $\begin{array}{l}80.48 \\
2672\end{array}$ & $\begin{array}{l}34.4 \\
21.93\end{array}$ & $\begin{array}{l}32.89 \\
24.34\end{array}$ & $\begin{array}{l}26.88 \\
4185\end{array}$ & $\begin{array}{r}34.56 \\
1258\end{array}$ & $\begin{array}{l}42.04 \\
4200\end{array}$ & 228 & 61.94 & $\begin{array}{l}60.17 \\
2 ? 82\end{array}$ & 38.7 \\
\hline $\begin{array}{l}\mathrm{Y} \\
\mathrm{Zr}\end{array}$ & $\begin{array}{l}19.88 \\
207.46\end{array}$ & $\begin{array}{c}31.54 \\
162\end{array}$ & $\begin{array}{l}171.98 \\
238.99\end{array}$ & $\begin{array}{l}49.2 \\
141\end{array}$ & $\begin{array}{c}26.72 \\
165\end{array}$ & $\begin{array}{l}21.83 \\
182.77\end{array}$ & $\begin{array}{c}24.34 \\
163\end{array}$ & $\begin{array}{c}41.85 \\
149\end{array}$ & $\begin{array}{l}121.58 \\
172.97\end{array}$ & $\begin{array}{c}82.02 \\
141\end{array}$ & $\begin{array}{l}20 \\
126\end{array}$ & $\begin{array}{c}22.47 \\
139\end{array}$ & $\begin{array}{c}22.82 \\
130\end{array}$ & $\begin{array}{c}18.54 \\
126\end{array}$ \\
\hline $\mathrm{Nb}$ & & 10.92 & 11.32 & 8.39 & 11.03 & 11.51 & 9.85 & 8.22 & 9.74 & 8.28 & 7.1 & 8.62 & 8.19 & $\begin{array}{l}126 \\
7\end{array}$ \\
\hline $\mathrm{Cs}$ & 15.92 & 2.98 & 19.73 & 4.8 & 4.41 & 6.22 & 3.83 & 1.61 & 3.14 & $\begin{array}{l}0.20 \\
7.89\end{array}$ & 5.83 & $\begin{array}{l}0.02 \\
8.3\end{array}$ & $\begin{array}{l}0.54 \\
7.54\end{array}$ & 7.84 \\
\hline $\mathrm{Ba}$ & 696.92 & 1204 & 677.58 & 700 & 977 & 1092.59 & 661 & $\begin{array}{l}1.108 \\
1108\end{array}$ & 1436.93 & 1805 & 464 & 869 & 560 & 560 \\
\hline $\mathrm{La}$ & $\begin{array}{l}31.7 \\
6410\end{array}$ & $\begin{array}{l}34.69 \\
66132\end{array}$ & $\begin{array}{l}35.66 \\
6038\end{array}$ & $\begin{array}{l}33.848 \\
40.650\end{array}$ & $\begin{array}{l}30.424 \\
5640\end{array}$ & $\begin{array}{l}37.26 \\
6.41\end{array}$ & $\begin{array}{l}17.383 \\
41804\end{array}$ & 20.025 & $\begin{array}{l}17.2 \\
2093\end{array}$ & $\begin{array}{l}57.892 \\
75245\end{array}$ & $\begin{array}{l}21.349 \\
44365\end{array}$ & 22.921. & $\begin{array}{r}23.771 \\
48763\end{array}$ & $\begin{array}{l}15.903 \\
38108\end{array}$ \\
\hline $\mathrm{Ce}$ & 64.19 & 66.132 & 69.38 & 49.659 & 56.49 & 63.41 & 41.004 & 17.305 & 22.93 & 75.245 & 44.356 & 47.217 & 48.736 & 38.128 \\
\hline $\begin{array}{l}\mathrm{Pr} \\
\mathrm{Nd}\end{array}$ & $\begin{array}{l}7.6 \\
2803\end{array}$ & $\begin{array}{l}7.997 \\
30806\end{array}$ & $\begin{array}{l}8.15 \\
2061\end{array}$ & $\begin{array}{l}9.684 \\
38391\end{array}$ & $\begin{array}{l}6.969 \\
2649\end{array}$ & $\begin{array}{l}7.77 \\
2833\end{array}$ & 5.1341 & $\begin{array}{l}6.096 \\
247723\end{array}$ & $\begin{array}{l}4.19 \\
164\end{array}$ & $\begin{array}{l}14.809 \\
5.5598\end{array}$ & $\begin{array}{l}5.325 \\
10903\end{array}$ & 5.475 & 5.616 & $\begin{array}{l}4.264 \\
6.10\end{array}$ \\
\hline $\begin{array}{l}\mathrm{Nd} \\
\mathrm{Sm}\end{array}$ & $\begin{array}{l}28.03 \\
5.22\end{array}$ & $\begin{array}{l}30.806 \\
5.947\end{array}$ & $\begin{array}{l}29.61 \\
5.43\end{array}$ & $\begin{array}{l}38.391 \\
8.272\end{array}$ & $\begin{array}{l}26.419 \\
5.188\end{array}$ & $\begin{array}{l}28.33 \\
5.34\end{array}$ & $\begin{array}{l}20.71 \\
4.485\end{array}$ & $\begin{array}{l}24.723 \\
5.214\end{array}$ & $\begin{array}{l}16.4 \\
3.31\end{array}$ & $\begin{array}{l}56.588 \\
11.477\end{array}$ & $\begin{array}{l}19.953 \\
4.077\end{array}$ & $\begin{array}{l}20.545 \\
3.942\end{array}$ & $\begin{array}{l}20.76 \\
3.87\end{array}$ & $\begin{array}{l}16.19 \\
3.255\end{array}$ \\
\hline $\begin{array}{l}\text { Sm } \\
\text { Eu }\end{array}$ & $\begin{array}{l}3.22 \\
0.61\end{array}$ & $\begin{array}{l}5.947 \\
1.318\end{array}$ & $\begin{array}{l}3.43 \\
0.73\end{array}$ & $\begin{array}{l}8.272 \\
1.767\end{array}$ & 1.246 & 0.79 & $\begin{array}{l}\begin{array}{l}4.483 \\
0.844\end{array} \\
0\end{array}$ & & $\begin{array}{l}3.31 \\
0.81\end{array}$ & & $\begin{array}{l}4.988 \\
0.988\end{array}$ & & $\begin{array}{llll} & 0.812 \\
0.832 & & \end{array}$ & 0.757 \\
\hline $\mathrm{Gd}$ & 4.44 & 5.419 & 4.29 & 8.216 & $\begin{array}{l}4.534 \\
4.540\end{array}$ & 4.52 & 4.467 & 6.286 & 3.14 & 11.978 & 3.715 & 3.454 & 3.481 & 2.972 \\
\hline $\mathrm{Tb}$ & 0.6 & 0.826 & 0.66 & 1.27 & 0.705 & 0.69 & 0.661 & 0.843 & 0.48 & 1.794 & 0.578 & 0.543 & 0.553 & 0.473 \\
\hline Dy & $\begin{array}{l}3.83 \\
0.78\end{array}$ & $\begin{array}{l}4.715 \\
0.087\end{array}$ & $\begin{array}{l}3.58 \\
0.74\end{array}$ & $\begin{array}{l}7.396 \\
1612\end{array}$ & $\begin{array}{l}4.111 \\
0842\end{array}$ & 3.92 & $\begin{array}{l}3.721 \\
0.752\end{array}$ & 5.197 & 2.7 & & $\begin{array}{l}3.449 \\
077\end{array}$ & & 3.323 & 2.766 \\
\hline Ho & 0.78 & 0.987 & 0.74 & $\begin{array}{l}1.612 \\
3.982\end{array}$ & 0.842 & 0.8 & $\begin{array}{l}0.752 \\
1027\end{array}$ & $\begin{array}{l}1.117 \\
30059\end{array}$ & 0.52 & $\begin{array}{r}2.004 \\
4893\end{array}$ & $\begin{array}{c}0.72 \\
11098\end{array}$ & 0.715 & 0.712 & \\
\hline $\begin{array}{l}\mathrm{Er} \\
\mathrm{Tm}\end{array}$ & $\begin{array}{l}2.23 \\
0.32\end{array}$ & $\begin{array}{l}2.5399 \\
0.37\end{array}$ & $\begin{array}{l}2.13 \\
0.33\end{array}$ & $\begin{array}{l}3.982 \\
0.59\end{array}$ & $\begin{array}{l}2.36 \\
0.36\end{array}$ & $\begin{array}{l}2.21 \\
0.33\end{array}$ & $\begin{array}{l}1.927 \\
0.28\end{array}$ & $\begin{array}{l}3.0059 \\
0.49\end{array}$ & $\begin{array}{l}1.4 \\
12\end{array}$ & $\begin{array}{l}4.893 \\
0.69\end{array}$ & $\begin{array}{l}11998 \\
0.35\end{array}$ & $\begin{array}{l}2.038 \\
0.32\end{array}$ & 1.952 & 1.532 \\
\hline $\mathrm{Yb}$ & 2.09 & 2.339 & 2.23 & 3.2 & 2.258 & 2.16 & $\begin{array}{l}1.609 \\
1.669\end{array}$ & $\begin{array}{l}2.711 \\
2.711\end{array}$ & $\begin{array}{l}1.26 \\
1.26\end{array}$ & 3.06 & 1.93 & 1.935 & 1.862 & $\begin{array}{l}0.24 \\
1.432\end{array}$ \\
\hline $\mathrm{Lu}$ & 0.33 & 0.344 & 0.35 & 0.466 & 0.344 & 0.32 & 0.24 & 0.409 & 0.19 & 0.443 & 0.294 & 0.301 & 0.285 & 0.211 \\
\hline Hf & 6.18 & 4.35 & 7.82 & 3.91 & 4.35 & 6.42 & 4.44 & 3.9 & 5.6 & 3.97 & 3.47 & 3.88 & 3.61 & 3.46 \\
\hline $\begin{array}{l}\mathrm{Ta} \\
\mathrm{Pb} \\
\mathrm{Pb}\end{array}$ & 1.98 & 0.84 & 1.72 & 0.6 & 0.81 & 2.02 & 0.78 & 0.6 & & & 0.55 & & & 0.57 \\
\hline $\begin{array}{l}\text { Pb } \\
\text { Th }\end{array}$ & $\begin{array}{l}63.67 \\
1.47\end{array}$ & $\begin{array}{r}208 \\
10.17\end{array}$ & $\begin{array}{l}13.96 \\
1.573\end{array}$ & $\begin{array}{l}9.91 \\
9.85\end{array}$ & $\begin{array}{l}9.53 \\
9.24\end{array}$ & $\begin{array}{l}9.24 \\
16\end{array}$ & $\begin{array}{l}8.5 \\
9.82 \\
9.82\end{array}$ & $\begin{array}{l}16.48 \\
778\end{array}$ & 10.515 & $\begin{array}{l}9.69 \\
8.85\end{array}$ & $\begin{array}{c}18 \\
7.83\end{array}$ & $\begin{array}{l}12.2 \\
8.96\end{array}$ & $\begin{array}{l}10.05 \\
8.33\end{array}$ & $\begin{array}{l}{ }_{11.37} \\
7.8\end{array}$ \\
\hline $\begin{array}{l}\mathrm{I}_{\mathrm{U}} \\
\mathrm{n}\end{array}$ & $\begin{array}{l}1.4 .41 \\
5.65\end{array}$ & $\begin{array}{l}1.06 \\
3.06\end{array}$ & 4.61 & $\begin{array}{l}7.83 \\
2.9\end{array}$ & $\begin{array}{l}9.24 \\
2.85 \\
\end{array}$ & $\begin{array}{l}10 \\
4.27\end{array}$ & $\begin{array}{l}9.82 \\
3.12\end{array}$ & $\begin{array}{l}. .8 \\
2.68\end{array}$ & $\begin{array}{l}10.18 \\
3.93\end{array}$ & $\begin{array}{l}8.68 \\
2.68\end{array}$ & 2.59 & $\begin{array}{l}8.90 \\
2.33\end{array}$ & $\begin{array}{l}8.53 \\
2.59\end{array}$ & $\begin{array}{l}2.8 \\
2.67\end{array}$ \\
\hline 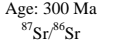 & & $0.710526 \pm 10$ & & $07423544+17$ & $0.7267673+20$ & & $0.7449414 \pm 16$ & $07476765+13$ & & & $0.703057 \pm 17$ & & & $745231 \pm 116$ \\
\hline${ }^{8 \mathrm{~S}} \mathrm{Rb} / \mathrm{si}$ & & 0.39015 & & 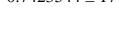 & $\begin{array}{c}0.12058 \\
5.2958\end{array}$ & & $0.1749414 \pm 10$ & $0.1410 / 03 \pm 10$ & & & 0.826 & 5.9456 & 5.88037 & $142211 \pm 11$ \\
\hline$\left.{ }^{87} \mathrm{Sr} r^{86} \mathrm{Sr}\right) \mathrm{i}$ & & 0.70886 & & & 0.70415 & & & & & & 0.70704 & 0.70552 & 0.70709 & \\
\hline$\varepsilon S r$ & & 66.9 & & & 0.17 & & & & & & 325.1 & 19.6 & 41.9 & \\
\hline${ }^{143} \mathrm{Nd}^{1 / 4} \mathrm{Nd}$ & $0.512235 \pm 4$ & $0.512184 \pm 3$ & $0.51213564 \pm 5$ & $0.512247 \pm 3$ & $0.512207 \pm 4$ & $0.5122009 \pm 5$ & & $0.512303 \pm 3$ & $0.512280 \pm 5$ & $0.512260 \pm 3$ & $0.512268 \pm 5$ & $0.512237 \pm 6$ & $0.512246 \pm 5$ & $1.512209 \pm 18$ \\
\hline${ }^{147} \mathrm{Sm} / /^{144} \mathrm{Nd}$ & 0.112575 & 0.117458 & 0.11086 & 0.130025 & 0.1187 & 0.11394 & & 0.12744 & 0.12207 & 0.1226 & 0.12352 & 0.11598 & 0.11268 & 0.12153 \\
\hline$\left({ }^{(43} \mathrm{N} d /{ }^{1 / 4} \mathrm{~N} d\right) \mathrm{i}$ & 0.512013 & 0.511953 & 0.51213 & 0.51199 & 0.51197 & 0.51198 & & 0.51205 & 0.51204 & 0.51202 & 0.51202 & 0.512 & 0.51202 & 0.51197 \\
\hline$\varepsilon \mathrm{Nd}$ & -4.6 & -5.8 & -2.21 & -5.1 & -5.42 & -5.2 & & -3.9 & -4.1 & -4.5 & -4.4 & -4.7 & -4.4 & -5.5 \\
\hline
\end{tabular}

